\title{
INTERNATIONALIZATION IN HIGHER EDUCATION, A CRITICAL REVIEW
}

\author{
HANS DE WIT \\ Boston College, Center for International Higher Education
}

\begin{abstract}
How do we understand the evolution of internationalization as a concept? Is a more diverse and inclusive internationalization replacing the western paradigm? Is there a shift in paradigm from cooperation to competition? Do we see an ongoing dominance of the internationalization abroad component at the cost of internationalization at home, or a more comprehensive and inclusive approach to internationalization? And is internationalization a key change agent towards innovation and global social responsibility of higher education? This contribution provides a critical reflection on internationalization in higher education, particularly in the current nationalist, populist and anti-global political climate! The challenges that institutions encounter are divers. There is pressure of revenue generation, competition for talents, and branding and reputation (rankings). There is pressure to focus on international research and publication, on recruitment of international students and scholars, and on the use of English as language of research and instruction. These challenges and pressures conflict with a more inclusive and less elitist approach to internationalization. In other words, there are tensions between a short term neoliberal approach to internationalization, focusing primarily on mobility and research, and a long term comprehensive quality approach, global learning for all.
\end{abstract}

Keywords: internationalization, higher education, cooperation, competition

Licensed under a Creative Commons Attribution-NonCommercial 4.0 International License Copyright is retained by the author(s) - https://creativecommons.org/licenses/by-nc/4.0/ 


\section{Internationalization in Higher Education, a Critical Review}

The international orientation of universities has changed dramatically over the centuries and takes substantially different and more complex forms and approaches today than in the previous centuries. What now is called 'internationalization of higher education' as a concept and strategy is a recent phenomenon that has emerged over the last 30 years, driven by a dynamic combination of political, economic, socio-cultural and academic rationales and stakeholders.

There is not one single model that drives internationalization, but at the same time, internationalization is still mainly considered in terms of a westernized, largely Anglo-Saxon, and predominantly English-speaking paradigm (Jones \& de Wit, 2012). Over the past decades, most scholarly and public attention with respect to internationalization in higher education has focused on the Western world. As Majee and Ress (2018) note: "Very little research has aimed to understand and conceptualise internationalisation efforts in the context of the historical particularities of the postcolonial condition." (p. 4). It is important "to learn from other nonwestern national and cultural contexts - to understand the full extent of internationalization as a phenomenon and what we can learn from each other in order to benefit students, employers and nations." (Jones \& de Wit, 2012, p. 50). But are these institutions, countries and regions simply mimicking the priorities of Anglo-Western forms of internationalisation, or are distinctive forms of the concept emerging which better reflect local needs and priorities? A recent study on national tertiary education policies and strategies in mid and low-income countries, seems to point to the first (de Wit, Rumbley, Craciun, Mihut, \& Woldegiyorgis, 2019).

How do we understand the evolution of internationalization as a concept? Is a more diverse and inclusive internationalization replacing the western paradigm? Is there a shift in paradigm from cooperation to competition, as Van der Wende (2001) observed? Do we see an ongoing dominance of the internationalization abroad component at the cost of internationalization at home, or a more comprehensive and inclusive approach to internationalization? And is internationalization a key change agent towards innovation and global social responsibility of higher education? Time for a critical reflection, in particular in the current nationalist, populist and anti-global political climate!

\section{Impact of massification and the knowledge economy}

Internationalization must be seen in the context of the changing role and position of higher education in the world. Internationalization can only be seen in its broader context.

Rapid changes are taking place in international higher education, which only have increased in range and complexity over the past decade. Key changes in higher education globally are its massification, the global knowledge economy, and the emphasis on reputation and rankings.

\section{Massification}

Once the privilege of an elite social class, gross enrollment ratios (GRE) in postsecondary education have mushroomed to more than $50 \%$ in many countries. There are more than 200 
million students studying globally at an untold number of institutions focusing on every specialization possible. In much of the world, massification is a key phenomenon. Emerging economies, including China, India, and Latin America and the Caribbean (with gross enrollment ratios of $37 \%, 22 \%$ and $35 \%$, respectively), are expanding their enrollment rates toward $50 \%$ or more as is common in the developed world. Even countries in Africa, still at the elite phase of less than $15 \%$ of GRE, the demand for higher education as a result of improved primary and secondary education and an emerging middle-class, is rapidly expanding.

On the other side, one can observe a saturation in demand in countries which already have moved far beyond the 50\% GRE characteristic of universal enrollment, such as the United States, the United Kingdom, continental Europe, Canada, Australia, South Korea and Japan. In those places, for demographic and other reasons, the supply of tertiary places in particular in STEM fields is starting to become higher than demand.

The relationship between massification and internationalization is manifest. International students and scholars are needed to fill the demand for graduates in these fields. Such students are mainly coming from the developing and emerging economies, where there is still an ongoing demand for quality higher education, resulting in brain drain and related decrease in research and top talent capacity in these countries. In the current anti-immigration climate, tensions increase between the need for imported high skilled talents and the desire to reduce the influx of immigrants.

\section{The global knowledge economy}

The other key element in higher education development and in internationalization in the past half-century has been the impact of the global knowledge economy - the increasingly technology and science based globalized set of economic relations that requires high levels of knowledge, skills, and sophisticated international relations. Research-intensive universities play a particularly important part in the global knowledge economy. Not only do they educate top talent but they are also the main producers of basic research in most countries. Research universities are among the main internationally-linked institutions. They have strong links with similar institutions around the globe, host international faculty and students, and increasingly function in the global language of science and scholarship-English.

\section{Reputation and rankings}

National, regional and global university rankings are driving the agendas of institutional leaders and national governments more than ever. Many governments, in particular in the North but increasingly also in the South, create excellence programs and investment schemes to become more globally competitive, have world-class universities and move higher in the rankings. While on the one hand there is a call for more access and equity, governments and institutions of higher education are striving for more excellence in research and teaching and learning. 
Rankings - national, regional, global, institutional, by discipline and across an increasing number of other dimensions - have come to play an ever more important role in higher education. Global ranking has remade global higher education in three ways, according to Marginson (2017). First, competition, the idea of higher education as a competitive market of universities and countries. Second, hierarchy, as a core element of the system of valuation. Third, performance, a performance economy driving "an often frenetic culture of continuous improvement in each institution." (Marginson, 2017, p. 7). Yudkevich, Altbach, and Rumbley (2016) speak of the "Global Academic Rankings Game", in which only a small portion of the higher education sector competes. This minority of institutions gets all the attention and forces governments and institutions to "compete" without acknowledging the need for differentiation. As Altbach and Hazelkorn (2017) state: "Prestige and reputation have become dominant drivers rather than pursuance of quality and student achievement, intensifying social stratification and reputational differentiation." (p. 10).

The relationship between excellence initiatives, rankings and internationalization is clear. They reflect the global competitive nature of higher education of the elite research universities, they stimulate competition for international students and scholars, and they are driven by quantitative international indicators: number of international students, number of international staff, and number of international co-authors of publications. It drives national governments and institutions to invest in more global research, to use English as language of research and education, and to focus on international recruitment strategies.

\section{Implications for internationalization}

The emphasis in internationalization has traditionally been on exchange and co-operation and there continues to be a rhetoric around the need to understand different cultures and their languages. Nevertheless, a gradual but increasingly visible shift has been apparent since the second half of the 1990's towards a more competitive internationalization. Van der Wende (2001) calls this a shift in paradigm from cooperation to competition. Competition for students, for scholars, for talents for the knowledge economy, for funding of complex research, for access to the top 500 in global rankings, and for access to high impact publications. Recruitment, excellence in research and reputation are driving the internationalization agenda of institutions and national governments, at the cost of the large majority of tertiary education institutions and their students and staff.

According to de Wit, Hunter, Howard, and Egon-Polak (2015), internationalization needs to evolve into a more comprehensive, more intentional, and less elitist (for all students and staff) process, less focused on mobility and less economically driven, with the goal to enhance the quality of education and research and make a meaningful contribution to society. How successful are we in changing the direction to a more competitive approach described above? 


\section{Internationalization, an evolving concept}

A gradual move of international education from margin to core has taken place from the 1980s onwards as a consequence of such developments as the increasing importance of research and education for economic development (the knowledge economy and society), the rapidly growing demand for higher education in the world, the end of the Cold War, and regional cooperation in higher education, the later particularly in Europe.

In general terms one can say that internationalization over the past 30 years has seen the following key characteristics:

- More focused on internationalization abroad than on internationalization at home

- More ad hoc, fragmented and marginal than strategic, comprehensive and central in policies

- More in the interest of a small, elite subset of students and faculty than focused on global and intercultural outcomes for all

- Directed by a constantly shifting range of political, economic, social/cultural, and educational rationales, with increasing focus on economic motivations

- Increasingly driven by national, regional, and global rankings

- Little alignment between the international dimensions of the three core functions of higher education: education, research, and service to society

- Primarily a strategic choice and focus of institutions of higher education, and less a priority of national governments

- Less important in emerging and developing economies, and more of a particular strategic concern among developed economies.

\section{Internationalization of the curriculum at home}

In the past decade, however, one can observe a reaction to these trends. While mobility is still the most dominant factor in internationalization policies worldwide, there is increasing attention being paid to internationalization of the curriculum at home. There is also a stronger call for comprehensive internationalization, which addresses all aspects of education in an integrated way. Although economic rationales and rankings still drive the agenda of internationalization, there is more emphasis now being placed on other motivations for internationalization. For example, attention is being paid to integrating international dimensions into tertiary education quality assurance mechanisms, institutional policies related to student learning outcomes, and the work of national and discipline-specific accreditation agencies.

In other words, internationalization in higher education has evolved over the past 30 years from a rather ad hoc, marginal and fragmented phenomenon to a more central and comprehensive component of higher education policy - although still more in rhetoric than in concrete action (de Wit \& Rumbley, 2017).

Leask, Jones and de Wit (2018) for that reason state that the implementation of "internationalization of the curriculum at home" appears to be struggling to move beyond good intentions and isolated examples of good practice. According to them we are still far away from 
any form of internationalization that is inclusive and accessible rather than elitist and exclusive, reason why they call for urgent attention to the following as a minimum:

1. We must, as scholars and practitioners, not only continue but also escalate our efforts at working together across disciplines, professional areas and national boundaries as well as within universities.

2. We must engage more with stakeholder groups beyond the academy, striving towards the common goal of creating a better, more equal and fairer world.

3. We must integrate internationalization with other agendas - disciplinary, professional, institutional, national, and regional - which are also focused on improving the quality of education and research for all students. Internationalisation of the curriculum, teaching, learning and service should not operate in a vacuum.

4. We must place emphasis on enhancing the quality of education and research for all students and staff in all parts of the world. This requires integrated policy and strategy as well as cooperation and partnership within and between institutions across the globe.

De Wit and Leask (2019) call for new ways of becoming and being international, and Brandenburg, de Wit, Jones and Leask (2019) call for an internationalization of higher education for society, more directed to the role of higher education in solving global problems, the Sustainable Development Goals of the United Nations.

Working towards inclusive international and intercultural learning for all, means according to them that we become more respectful of diverse contexts, agendas and perspectives on a global scale. As internationalization has moved from the margins of higher education research, policy and practice, it has become clear that the previously disjointed approaches that characterized its earliest years have given way to an understanding that sophisticated synergies are required to realize its full potential.

\section{Internationalization reconsidered}

As internationalization and global engagement become entrenched around the world as mainstream components of quality in higher education, the need to ensure high quality professional preparation of those responsible for the internationalization agenda in their respective institutions or systems of higher education becomes more widespread and sustained. This is reflected well in the notion of "intelligent internationalization," as expressed by Rumbley (2015):

"Intelligent internationalization" demands the development of a thoughtful alliance between the research, practitioner, and policy communities. Those participating in the elaboration of internationalization activities and agendas [must] have access to the information, ideas, and professional skill-building opportunities that will enhance their ability to navigate the complex and volatile higher education environment of the next 20 years. (p. 17)

In tandem, an updated definition of internationalization emerged, reflecting these broader understandings of the nature and purpose of internationalization: 
The intentional process of integrating an international, intercultural or global dimension into the purpose, functions and delivery of post-secondary education, in order to enhance the quality of education and research for all students and staff, and to make a meaningful contribution to society. (de Wit et al, 2015, p. 29)

According to most recent survey results from the $5^{\text {th }}$ Global survey on Internationalization by the International Association of Universities (IAU) two thirds of university leaders around the world are considering internationalization as an important agenda issue, although Marinoni and de Wit (2019) observe that there is an increasing divide between institutions that consider internationalization as of high importance and those not. They observe that

[t]he reasons for such a divide between HEIs that consider internationalisation extremely important and those who do not is worth a reflection and deserves to be studied more in depth, especially if one considers internationalisation to be an essential part of all HEIs' mission and a sign of quality. (para. 29)

As described above, the challenges that institutions encounter in their internationalization strategy are divers. There is pressure of revenue generation, competition for talents, and branding and reputation (rankings). There is pressure to focus on international research and publication, on recruitment of international students and scholars, and on the use of English as language of research and instruction. These challenges and pressures conflict with a more inclusive and less elitist approach to internationalization, building on the needs and opportunities of own student and staff. In other words, there are tensions between a short term neoliberal approach to internationalization, focusing primarily on mobility and research, and a long term comprehensive quality approach, global learning for all.

The main misconception about internationalization is that we consider internationalization too much as a goal in itself instead of as a means to an end. Internationalization is not more and less than a way to enhance the quality of education and research, and service to society. That quality and related internationalization as defined by de Wit et all (2015) is under pressure, and the current global political climate (Altbach \& de Wit, 2017) is not supportive in reversing the trend, on the contrary. A more inclusive approach to internationalization as described above by de Wit et all in their definition, and by the urgent actions called for by de Wit and Leask (2019) and by Brandenburg et all (2019) is more than ever needed. 


\section{References}

Altbach, P. G., \& de Wit, H. (2017, September 15). The new nationalism and internationalisation of HE. University World News.

Altbach, P. G., \& Hazelkorn, E. (2017). Pursuing rankings in the age of massification: For most - forget about it. International Higher Education, 89, 8-10.

Brandenburg, U., de Wit, H., Jones, E., \& Leask, B. (2019, April 20). Internationalisation in higher education for society. University World News.

de Wit, H., \& Leask, B. (2019, July 28). Towards new ways of becoming and being international. University World News.

de Wit, H., \& Rumbley, L. E. (2017). Professional development in international education: The example of the Boston College MA in international higher education. Internationalisation of Higher Education, A Handbook, 3, 2-14.

de Wit, H., Hunter, F., Howard L., \& Egron-Polak, E. (Eds). (2015) Internationalisation of Higher Education. Brussels: European Parliament, Directorate-General for Internal Policies.

de Wit, H., Rumbley, L. E., Craciun, D., Mihut, G., \& Woldegiyorgis, A. (2019). International mapping of national tertiary education internationalization strategies and plans (NTEISPS) (CIHE Perspectives no. 12), Boston: Center for International Higher Education.

Hunter, F., \& de Wit, H. (2016). The European landscape: A shifting perspective. Internationalization of Higher Education, A Handbook, 2, 49-68.

Jones, E., \& de Wit, H. (2012). Globalization of internationalization: Thematic and regional reflections on a traditional concept. AUDEM: The International Journal of Higher Education and Democracy, 3, 35-54. doi:10.1353/aud.2012.0012

Knight, J. (2012). Concepts, rationales, and interpretive frameworks in the internationalization of higher education. In D. K. Deardorff, H. de Wit, J. Heyl, \& T. Adams (Eds.), The SAGE handbook on international higher education (pp. 27-42). Thousand Oaks, CA: Sage Publications.

Leask, B., Jones, E., \& de Wit, H. (2018, December 7). Towards inclusive intercultural learning for all. University World News.

Majee, U. S., \& Ress, S. B. (2018). Colonial legacies in internationalisation of higher education: Racial justice and geopolitical redress in South Africa and Brazil. Compare: A Journal of Comparative and International Education. doi:10.1080/03057925.2018.1521264

Marginson, S. (2017). Do rankings drive better academic performance? International Higher Education, 89, 6-7.

Marinoni, G. \& de Wit, H. (2019, January). Internationalization and inequality. First results from the 5th Global Survey of IAU. University World News.

Proctor, D., \& Rumbley, L. E. (2018). The future agenda for internationalization in higher education: Next generation insights into research, policy, and practice. London and New York: Routledge.

Rumbley, L. E. (2015). “Intelligent internationalization”: A $21^{\text {st }}$ century imperative. International Higher Education, 80, 16-17. 
Van der Wende, M. (2001). Internationalization policies: About new trends and contrasting paradigms. Higher Education Policy, 14, 249-259.

Yudkevich, M., Altbach, P. G., \& Rumbley, L. E. (Eds) (2016). The global academic rankings game: Changing institutional policy, practice, and academic life, New York: Routledge. 